Article Type: Research Paper

\title{
Determinants of Intellectual Capital Disclosure in Non-Vocational Higher Education in Indonesia
}

\author{
Indah Cahyani Gobel ${ }^{1}$, Ahmad Juanda ${ }^{2} *$, Ihyaul Ulum ${ }^{3}$, and Mudrifah ${ }^{4}$
}

\section{aPEN}

\section{AFFILIATION:}

1,2,3,4 Department of Accounting, Universitas Muhammadiyah Malang, East Java, Indonesia.

\section{*CORRESPONDENCE:}

juanda@umm.ac.id

\section{THIS ARTICLE IS AVAILABLE IN:}

http://journal.umy.ac.id/index.php/ai

DOI: 10.18196/jai.2102154

\section{CITATION:}

Gobel, I. C., Ulum, I., Juanda, A. \& Mudrifah. (2020). Determinants of Intellectual Capital Disclosure in Non-Vocational Higher Education in Indonesia. Journal of Accounting and Investment, 21(2), 362-382.

\section{ARTICLE HISTORY}

Received:

8 Jan 2020

Reviewed:

20 Feb 2020

30 Mar 2020

Revised:

25 Mar 2020

15 Apr 2020

Accepted:

18 Apr 2020

\begin{abstract}
:
Research aims: This study aims to examine how intellectual capital (IC) disclosure has been carried out by Indonesian higher education institutions (HEI). In addition, this study examines the determinants of IC disclosure, namely age, size and accreditation status of $\mathrm{HEl}$.

Design/Methodology/Approach: The IC components used in this study refers to Ulum (2019), which modified the research from Leitner and Karl-Heinz (2002).

This modification refers to the Study Program Accreditation Instrument (IAPS) 4.0 which has been regulated by the National Accreditation Board for Higher Education. The hypotheses test is conducted using SEM PLS.

Research findings: The test results show that the age, size and accreditation status variables have a significant effect on intellectual capital disclosure (ICD). Theoretical contribution/ Originality: This study examines the IC disclosure with IAPS 4.0 that has just been applied in Indonesia.

Practitioner/Policy implication: The study results provide an overview of the factors that drive IC disclosure in Indonesian HEI.

Research limitation/Implication: This study only involved 86 large Indonesian non-vocational HEl.
\end{abstract}

Keywords: Intellectual Capital; Disclosure; Non-Vocational Higher Education

\section{Introduction}

Intellectual capital (IC) has become an issue for various sectors such as manufacturing, banking, including universities. A positive role of IC for the company both in terms of disclosure and IC performance, has made many academics focus on further studying the potential of IC and its contribution to the organization (see: Clarke, Seng, and Whiting (2011); Orens, Aerts, \& Lybaert, 2009; Tran \& Vo, 2020). Furthermore, higher education becomes the object of great attention in the development of IC outside the conventional / profit-oriented pathway. Since the primary purpose of higher education is to produce and disseminate knowledge, and no less important is the research and development of human resources (Cañibano \& Sanchez, 2008). The academic community and the general public consider that IC universities must reach the highest level of excellence and do not require any kind of interference, but in reality universities are still slow in innovating (Fazlagic, 2005). 
Based on European-Commission (2006), IC is defined as a combination of intangible resources and organizational activities in changing the quantity of material, financial, and human resources in a system that can create a value. Bukh, Nielsen, Gormsen, and Mouritsen (2005) define IC as the process of creating value for an organization from various combinations of knowledge resources in the form of employees, customers, processes or technology. Higher Education is part of the science, education and innovation system of the nation and knowledge producers. The output from the most important universities is knowledge incorporated in the results of new research, publications and educated students. Thus, the most valuable resources of the university are students with their organizational networks. These resources can be interpreted as intangible assets, although the term has not been disclosed in the university (Leitner, 2004).

Kong and Bezhani (2010) have done prior research about IC reporting in the 30 universities in UK. The results of this study indicate that the amount of IC information disclosed in the UK university's annual report is low. In Indonesia IC research still lacks attention. One of the first studies related to IC disclosure in Indonesia was conducted by Ulum and Novianty (2012). They examined the disclosure of IC on the official website of Indonesian universities and found that in general the disclosure of IC on the official website of the university winning the QS-Star was still low because none of the tertiary institutions revealed 46 items in full about IC.

Pratiwi (2012) also examined the disclosure of IC in 35 QS-Star winning universities in Indonesia with three components: human capital, structural capital and relational capital where the measurement indicators consisted of 46 items. Their results state that the highest IC disclosure in human capital, structural capital, and relational capital is Airlangga University, while the lowest is the Bandung National Institute of Technology. Furthermore, Ulum, Malik, and Sofyani (2019) found that although the IC disclosure rate of many universities in Indonesia was higher than universities in Malaysia, the disclosure rate only reached $50 \%$ of the total items that should have been disclosed. This result indicates that university management's commitment to IC disclosure is still low.

Prior research on IC determinants at a university was conducted by Fathony and Ulum (2018). They found that IC disclosure was related to the number of students. To this day research on the determinants of IC disclosure at universities in Indonesia is rarely found. Therefore, this study aims to close the gap. Ulum, Harviana, Zubaidah, and Jati (2019) found that IC disclosure by universities had a positive effect on the interests of prospective students. This result shows the importance of IC disclosure, especially related to going concern issues from university entities.

Explicitly, this study aims to examine the disclosure of IC at the university and examine its determinants namely age, size and accreditation status of IC disclosure. This study refers to the IC disclosure research conducted by Ulum (2019) who modified the research from Leitner (2004). Previous research on the effect of university size and age on intellectual capital disclosure (ICD) was conducted by Fathony and Ulum (2018). However, the study failed to support the influence of the two determinants on ICD. In 
contrast to the research, the current research uses IC disclosure indicators which refer to the Study Program Accreditation Instrument 4.0 (IAPS) which is newly regulated by the National Accreditation Board for Higher Education (BAN-PT) which is then modified. It is intended that the disclosure of IC universities in Indonesia following the applicable accreditation regulations.

This research contributes to the study of IC disclosure in universities and its determinants considering that this still receives minimal attention from academics, especially Indonesia as a context of study in developing countries. Practically, this study provides an overview of university stakeholders about the extent to which ICs have been disclosed and what factors are decisive. Thus, university management can make the results of this research as input for IC development and increased IC disclosure at universities.

\section{Literature Review and Hypotheses Development}

\section{Stakeholder Theory}

Freeman and Reed (1983) define stakeholders as "... any group or individual who can affect or is affected by the achievements of the organization's objectives". This theory suggests that the management of an organization is required to carry out activities expected by stakeholders because stakeholders have the right to know information about the activities of companies that affect them. The theory also states that all stakeholders have the right to be provided with information about the activities of organizations that affect them (for example, through pollution, sponsorships and security initiatives), even when they choose not to use that information or when they cannot directly play a constructive role in organizational survival (Deegan \& Unerman, 2011). According to Purnomosidhi (2005), reporting organizational activities is not limited to reporting economic or financial performance. Thus, IC information reporting other than mandatory disclosure is also important to do. Furthermore, Craig Deegan and Soltys (2007) states that stakeholder theory emphasizes organizational accountability far beyond simple financial or economic performance. This theory states that organizations will voluntarily disclose information about their environmental, social and intellectual performance, exceeding and above their mandatory requests, to meet actual or acknowledged stakeholder expectations.

In term of IC disclosure, stakeholder theory can be viewed from two sides namely ethical (moral) and managerial aspects. From the ethical side it is believed that all stakeholders have the right to be treated fairly by the organization, managers must manage the organization for the benefit of all stakeholders (Deegan, 2004). Managers have fulfilled the ethical aspects of this theory when managers are able to manage the organization to its full potential, especially in the effort to create value for an organization, it means that managers have fulfilled the ethical aspects of this theory. From the managerial field, IC is concerned with value creation, in this context it is by utilizing all the potential of the company: human capital, capital structure, and relational capital The good management 
of all this potential will create value for an organization, which can then drive the organization's performance for the benefit of stakeholders. With the disclosure of IC, stakeholders will be able to see to what extent the organization is able to produce added value for the organization.

\section{Research Hypotheses}

This research is not only descriptive, but it also tests the influence of three variables that are inherent in the disclosure of IC, namely age, size and accreditation status. Research about relationship of college age with disclosure aspects has been conducted, but in the context of different disclosure studies and also in different countries. Banks, Fisher, and Nelson (1997) found that older universities tended to have better disclosure quality than younger universities in terms of service for financial performance. Ismail and Bakar (2011) who examined the level of accountability for disclosure of information in annual reports and websites at Malaysian state universities also found similar results. Based on the description above, just entering the university's size will also affect intellectual capital disclosure. Thus, this study proposes a hypothesis:

$\boldsymbol{H}_{1}$ : University age has a positive effect on intellectual capital disclosure.

Company size relates to the disclosure of intellectual capital as explained in the legitimacy theory (Guthrie, Petty, Yongvanich, \& Ricceri, 2004). The higher the size of the company, the greater the responsibility the company has for the community. One form of responsibility is to disclose IC. Research related to the relationship between university size and the disclosure of intellectual capital in higher education has been conducted Fathony and Ulum (2018). The results of the study stated that the size of the university assessed by the number of students had a significant effect on IC disclosure. In contrast to Fathony and Ulum's research (2018), in this study the size of the university was measured by the number of students, the number of lecturers, the number of faculties, and the number of study programs. Thus, the university's size is more comprehensive, so it is expected to obtain more accurate results. Based on the description above, this study proposes the hypothesis:

$\boldsymbol{H}_{2}$ : The size of the university has a positive effect on the disclosure of Intellectual Capital.

The accreditation status of a university indicates the quality of an university and therefore is a vital thing seen by many people, especially prospective new students (Kamal \& Rahmadiane, 2017). Accreditation status is strongly influenced by the quality of human resources owned by a university, which quality can be seen and identified from IC component items disclosed by the university. Therefore, the better the accreditation status of a campus indicates the better intellectual capital owned by the campus. To attract prospective students, the campus will tend to intens express their intellectual capital (Ulum et al., 2019). Based on the description above, this study proposes the third hypothesis: 
$\boldsymbol{H}_{3}$ : Accreditation status has a positive effect on the extent of intellectual capital disclosure.

\section{Research Method}

This type of research is an associative descriptive research that is research that describes the information with the actual situation and analyzes the relationship between variables with one another (Cooper \& Schindler, 2001). The population in this study is the best non-vocational tertiary institution in Indonesia, taken from the Ministry of Research, Technology \& Higher Education version 2018. The sampling technique used by researchers is purposive sampling, which is a method of determining samples based on certain criteria. The criteria for determining the sample in this study are the best nonvocational tertiary institutions in Ministry of Research, Technology \& Higher Education version and registered in Clusters 1 and 2 in its version. This criterion is used as a basis for sampling on the grounds that clusters 1 and 2 are universities that have relatively more mature human resources and knowledge compared to campuses in subsequent clusters 3 and 4 . It means, indirectly or unconsciously, universities cluster 1 and 2 have great attention to intellectual capital in their institutions.

\section{Definition of Variable Operations}

The dependent variable in this study is Intellectual Capital Disclosure. The IC component consists of three parts namely human capital, structural capital and relational capital, which consists of 60 items (Ulum, 2019), as shown in Table 1.

Table 1 IC disclosure items

\begin{tabular}{|c|c|c|}
\hline Human Capital & Structural Capital & Relational Capital \\
\hline 1. Number of Lecturers & $\begin{array}{l}\text { 31. Vision, Mission, Objectives } \\
\text { (VMT) }\end{array}$ & $\begin{array}{l}\text { 49. International } \\
\text { Cooperation in Education }\end{array}$ \\
\hline 2. Lecturer Qualifications & 32. VMT Achievement Strategy & $\begin{array}{l}\text { 50. International } \\
\text { Cooperation in Research }\end{array}$ \\
\hline 3. Lecturer Competencies & $\begin{array}{l}\text { 33. The Civil Procedure Systems } \\
\text { (good governance) }\end{array}$ & $\begin{array}{l}\text { 51. International } \\
\text { Cooperation in Community } \\
\text { Service }\end{array}$ \\
\hline 4. Lecturer Workload & 34. Quality Assurance System & $\begin{array}{l}\text { 52. National Cooperation in } \\
\text { Education }\end{array}$ \\
\hline $\begin{array}{l}\text { 5. Number of Lecturers with } \\
\text { Doctoral Education }\end{array}$ & 35. Student Selection System & $\begin{array}{l}\text { 53. National Cooperation in } \\
\text { Research }\end{array}$ \\
\hline 6. Number of Professor & 36. Student Services & $\begin{array}{l}\text { 54. National Cooperation in } \\
\text { the field of Public Service }\end{array}$ \\
\hline 7. Number of Head Lecturer & 37. HR Development Systems & $\begin{array}{l}\text { 55. Regional Cooperation in } \\
\text { Education }\end{array}$ \\
\hline $\begin{array}{l}\text { 8. Number of Lecturers who have } \\
\text { Competency / Educator } \\
\text { / Industry Certificates }\end{array}$ & $\begin{array}{l}\text { 38. Lecturer Research Funds } \\
\text { (internal sources) }\end{array}$ & $\begin{array}{l}\text { 56. Regional Cooperation in } \\
\text { Research }\end{array}$ \\
\hline
\end{tabular}

Source: (Ulum, 2019) 
Gobel, Juanda, Ulum, \& Mudrifah

Determinants of Intellectual Capital Disclosure in Non-Vocational Higher Education in Indonesia

Table 1 IC disclosure items (cont.)

\begin{tabular}{|c|c|c|}
\hline Human Capital & Structural Capital & Relational Capital \\
\hline 9. Number of Temporary Lecturers & $\begin{array}{l}\text { 39. Dedication Funds to the } \\
\text { Lecturer Community (internal } \\
\text { sources) }\end{array}$ & $\begin{array}{l}\text { 57. Regional Cooperation in } \\
\text { the field of Public Service }\end{array}$ \\
\hline 10. Number of Active Students & $\begin{array}{l}\text { 40. Tridharma Facilities and } \\
\text { Infrastructure }\end{array}$ & $\begin{array}{l}\text { 58. Total Education } \\
\text { Cooperation Fund }\end{array}$ \\
\hline 11. Number of New Students & 41. Academic Information Systems & $\begin{array}{l}\text { 59. Number of Research } \\
\text { Collaboration Funds }\end{array}$ \\
\hline 12. Number of Transfer Students & 42. e-Learning & $\begin{array}{l}\text { 60. Amount of Student } \\
\text { Creative Program } \\
\text { Collaboration Funds }\end{array}$ \\
\hline 13. Number of Overseas Students & 43. Library Information Systems & \\
\hline $\begin{array}{l}\text { 14. Number of Educational } \\
\text { Personnel }\end{array}$ & 44. Research Information Systems & \\
\hline $\begin{array}{l}\text { 15. Qualifications of Educational } \\
\text { Personnel }\end{array}$ & 45. Information Systems & \\
\hline $\begin{array}{l}\text { 16. Competencies of Educational } \\
\text { Personnel }\end{array}$ & 46. Curriculum & \\
\hline 17. Education Workforce Workload & 47. Learning System & \\
\hline 18. Recognition of Lecturer Expertise & $\begin{array}{l}\text { 48. Research and Community } \\
\text { Service Standards }\end{array}$ & \\
\hline \multicolumn{3}{|l|}{$\begin{array}{l}\text { 20. Scientific Work of a Lecturer in } \\
\text { Citation }\end{array}$} \\
\hline \multicolumn{3}{|l|}{ 21. Lecturer Products / Services } \\
\hline \multicolumn{3}{|l|}{ 22. Lecturer-Student Research } \\
\hline \multicolumn{3}{|l|}{$\begin{array}{l}\text { 23. Umbrella of Community Service } \\
\text { for Lecturer-Students }\end{array}$} \\
\hline \multicolumn{3}{|l|}{ 24. Student Academic Achievements } \\
\hline \multicolumn{3}{|l|}{ 25. Non-Academic Student } \\
\hline \multicolumn{3}{|l|}{ 26. Graduates Competitiveness } \\
\hline \multicolumn{3}{|l|}{ 27. Graduates' Performance } \\
\hline \multicolumn{3}{|l|}{$\begin{array}{l}\text { 28. Lecturer Scientific Publications } \\
\text { with Students }\end{array}$} \\
\hline \multicolumn{3}{|l|}{$\begin{array}{l}\text { 29. Number of Lecturer Articles } \\
\text { with Cited Students }\end{array}$} \\
\hline $\begin{array}{l}\text { 30. Products / services of Lecturers } \\
\text { with Students Adopted by the } \\
\text { Community / Industry }\end{array}$ & & \\
\hline
\end{tabular}

Source: (Ulum, 2019)

The independent variables in this study are university age, size, and accreditation status. Age is calculated since the founding of the university until the 27th of October 2019, the last date of data collection. The size is calculated from the number of students plus the number of lecturers, faculties and the number of study programs divided by four:

Number of students+Number of lecturers+Number of Faculties+Number of Departments 
Accreditation status Accreditation status is obtained from the National Accreditation Board for Higher Education (BAN-PT). Accreditation status is calculated from:

\section{Accreditation status of university+Accreditation status of departments}

$1+$ Number of Departments

From 86 universities there are four types of accreditation, A, B, C, and have not been accredited $i$, which is then measured by scoring, if $A$ is given a number $4, B$ is given a number $3, C$ is given a number 2 , and unaccredited is given a number 1 .

Sources of data from this study were obtained from the official websites of each nonvocational tertiary institution, and the official website of Ministry of Research, Technology and Higher Education. Data collection techniques in this study using documentation techniques. The documentation technique is used to obtain data that has already been made and has been processed by others (Ulum \& Juanda, 2018 ). This data was obtained using documentation by re-recording the data needed in the form of Ms. Excel.

Data analysis was performed with content analysis, a method for collecting and analyzing from a text. Text here can be in the form of words, numbers, and images that can be conveyed. Content analysis in this study was carried out with the six stages of the numerical coding system as presented in Table 2 .

Table 2 Six Ways Numerical Coding System

\begin{tabular}{cl}
\hline Code & \\
\hline 0 & Item not disclosed \\
1 & There is an item title, but no content \\
2 & Items are expressed in narrative format \\
3 & Items are expressed in number format \\
4 & Items are expressed in monetary unit format \\
5 & Items are expressed in graphic / chart / picture format \\
\hline
\end{tabular}

Source: (Ulum, 2019)

Further analysis was using statistic descriptive for explain measures such as the deployment of the average, minimum, maximum, standard deviation, and range on the sample data (Ulum \& Juanda, 2018). Next testing the hypothesis by using techniques of SEM (Structural Equation Modeling) with 6.0 WarpPLS program. SEM analysis techniques using the WarpPLS program are: Open / create project file , Raw of the data, pre-process data, Define of the variables and links in SEM Model, and Perform / view SEM analysis / results.

The steps in SEM WarpPLS testing that can be described are to assess the criteria of model fit. Conformity test between theoretical models and empirical data can be seen at the level (Goodness-of-fit statistics). A model is said to be fit if the covariance matrix of a model is the same as the covariance of the data matrix (observed). Model fit in the WarpPLS 6.0 program can be seen from the output of general results to judge based on the model fit indices and $\mathrm{P}$ values by using ten fit indicators, namely: 
1. The average path coefficient (APC) has a value of $P<0.05$

2. Average R-squared (ARS) has a $P$ value $<0.05$

3. Average adjusted $R$-squared (AARS) memiliki nilai $P<0.05$

4. The average block Variance Inflation Factor (AVIF) has a value $<5$ and ideally $<3.3$

5. Average full collinearity VIF (AFVIF) has a value $<5$ and ideally $<3.3$

6. Tenenhaus GoF (GoF) has a small value $>=0.1$, medium $>=0.25$, large $>=0.36$

7. Sympson's paradox ratio (SPR) has a value $>0.7$ and ideally 1

8. R-squared contribution ratio (RSCR) has a value $>0.9$ and ideally 1

9. Statistical suppression ratio (SSR) is accepted if the value $>0.7$

10. Nonlinear bivariate causality direction ratio (NLBCDR) is accepted if the value is $>0.7$

The indicators above can show the path coefficient and the $P$ value of each direct relationship in the research model. The fit indices and $p$ values model section displays the results of three fit indicators namely average path coefficient (APC), average Rsquared (ARS), and Average adjusted R-squared (AARS). P values for APC, ARS and AARS must be less than 0.05 or significant.

\section{Results and Discussion}

\section{Overview of Research Objects}

The object of this research is the disclosure of Intellectual Capital in non-vocational tertiary institutions in Indonesia. The ministry is used as a reference because the ministry is a ministry within the Indonesian government that conducts research, technology and tertiary institutions that are constantly moving and working to improve the quality of higher education in Indonesia and its assessment parameters can be easily seen and accessed. Ministry of Research, Technology and Higher Education ranking parameters are based on information obtained from various systems. The main components used by Ministry of Research, Technology and Higher Education as parameters include 5 (five) main components, namely: the quality of human resources, which includes the percentage of the number of dobtoral lecturers, the percentage of the number of head lecturers and professors, and the ratio of students to lecturers; Institutional quality, which includes the accreditation of institutions and study programs, the number of internationally accredited study programs, the number of international students and the number of university collaborations; The quality of student activities, which include student performance, the quality of research and community service, which includes research performance, community service performance, and the number of scopus indexed scientific articles per number of lecturers and; Quality of innovation, which includes innovation performance.

In addition, the indicators used in several main components also experienced adjustments, including the addition of higher education cooperation indicators in the main institutional components. The data analysis results at the Higher Education Database (PDDikti) of the Ministry of Research, Technology and Higher Education, data released by the Ministry of Research, Technology and other relevant sources, 5 (five) 
higher education clusters are obtained. The universities included in the 5 (five) clusters are as follows:

1. Cluster 1 numbered 14 universities;

2. Cluster 2 is 72 universities;

3. Cluster 3 totals 299 universities;

4. Cluster 4 totals 1,470 universities, and

5. Cluster 5 amounts to 155 tertiary institutions.

Based on the purposive sampling method set out in chapter III, a total of 86 nonvocational tertiary institutions are listed in the Ministry of Research, Technology and Higher Education ranking and have met the criteria. The sample selection procedures are presented in Table 3.

Table 3 Determination of the Number of Samples

\begin{tabular}{clc}
\hline No & \multicolumn{1}{c}{ Sample Criteria } & amount \\
\hline 1. & The best non-vocational tertiary education version of Ministry of & 100 \\
2. & Research, Technology and Higher Education in 2018 \\
& $\begin{array}{l}\text { Number education institutions arenot listed in Clusters } 1 \text { and } 2 . \\
\text { Education's best non-vocational colleges }\end{array}$ & $(14)$ \\
\hline
\end{tabular}

Of the 100 non-vocational tertiary institutions listed in 2018 Ministry of Research, Technology and Higher Education ranking, not all of the tertiary institutions met the criteria needed in this study. There are 14 companies are not included in clusters 1 and 2. So that universities that meet the sample criteria are 86 universities.

\section{Descriptive Data}

Table 4 shows the descriptive statistics of research data. It can be seen that the first independent variable is age, where the college that has the oldest age is the Theological Philosophy School in Jakarta with 85.2 years of age,and the college that has the youngest age is Yogyakarta Veterans National Development University with 5 years of age . Table 4.2 shows that the age has an average of 51.2437, with a standard deviation of 15.02238, which shows that there is no gap between the universities with the highest and lowest ages because the standard deviations are smaller than the average age of the tertiary institutions.

Table 4 Descriptive Statistics

\begin{tabular}{lccccc}
\hline & $N$ & Minimum & Maximum & Mean & Std. Deviation \\
\hline Age & 86 & 5.00 & 85.20 & 51.2437 & 15.02238 \\
Size & 86 & 58.00 & 16965.00 & 4065.0233 & 3575.60273 \\
Accreditation & 86 & 0.43 & 4.00 & 3.2860 & 0.46289 \\
ICD & 86 & 31.00 & 57.00 & 42.6512 & 5.68127 \\
\hline
\end{tabular}

The results of the presentation of descriptive statistics above also show that the maximum age of tertiary education is 85 years and the average age is 50 years and 
above. This can indicate that the age of tertiary institutions in Indonesia is still relatively large because the average age is still in the range of 50 years and above.

The second independent variable, namely size, also produces smaller standard deviations, with an average size of 4065.0233 where the university with the highest number of sizes is Brawijaya University with a total size of 16965.00, while the lowest is Jakarta Theological Philosophy College with a total size of 58.00 . Size in descriptive statistics shows an average value of 4,065 and a maximum value of 16,965 , meaning that the average size (number of students, lecturers, faculties, study programs) at universities in Indonesia is relatively large.

The third independent variable, namely accreditation, produces a smaller standard deviation compared to the average, where the National University which has the most number of accreditations is 4.00 , while the lowest is the Malang Institute of Technology with several 0.43 . Accreditation on descriptive statistics shows an average value of 3.28 while the maximum value is 4.00 . It shows that the average accreditation at tertiary institutions in Indonesia is still relatively small because it ranges between the accreditation scores of B.

The number of samples is 86 consist of the best non-vocational tertiary institutions in the Ministry of Research, Technology and Higher Education version, the average ICD was 42.6512 with a maximum of 57.00 expressed by Yogyakarta State universities and a minimum of 31.00 disclosed by Malang University of Technology. The standard deviation in the disclosure of intellectual capital shows that the standard deviation is smaller than the average value. This means that the results show good results, because good standard deviations reflect deviations from the sample data are smaller than the average value. The standard deviation shows that the ICD revealed by each of the best universities in the Ministry of Research, Technology and Higher Education version has almost the same magnitude between each sample of their universities.

\section{Content Analysis Result}

ICD can be described by content analysis, this analysis is used to collect IC item data that is disclosed on the official website of non-vocational tertiary institutions conducted by scoring. Scoring in the assessment of intellectual capital disclosures consists of the numbers $0,1,2,3,4$, and 5 . IC component reporting is presented as a value starting from " 0 " if the item is not disclosed, value " 1 " if there is an item title, but not it contains, the value of " 2 " items is expressed in narrative format, value " 3 " if items are expressed in number format, value " 4 " if items are disclosed in monetary format, and value " 5 " if items are expressed in graphic / chart / picture format . The ICD is presented in Figure 1. 


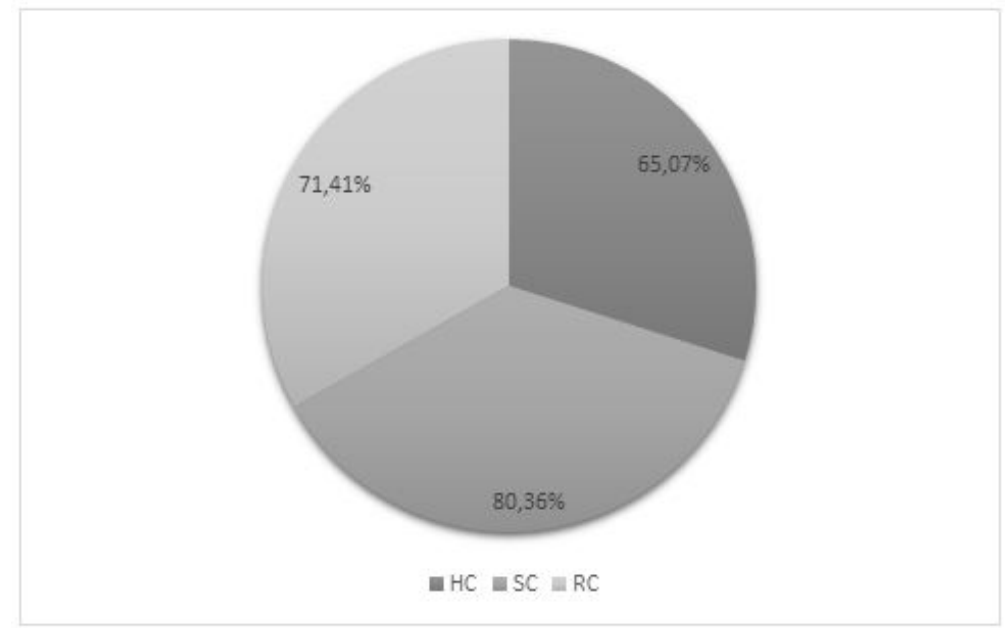

Note: HC: Human Capital; SC: Structural Capital; RC: Relational Capital

Figure 1 Disclosure of Intellectual Capital

Based on Figure 1, it can be seen that of the three components of intellectual capital disclosure, the highest disclosure is the structural component of capital with a percentage of disclosure of $80.36 \%$ Then the second highest is the relational capital component with a percentage of $71.41 \%$ and the lowest is the human component capital with a percentage of $65.07 \%$.

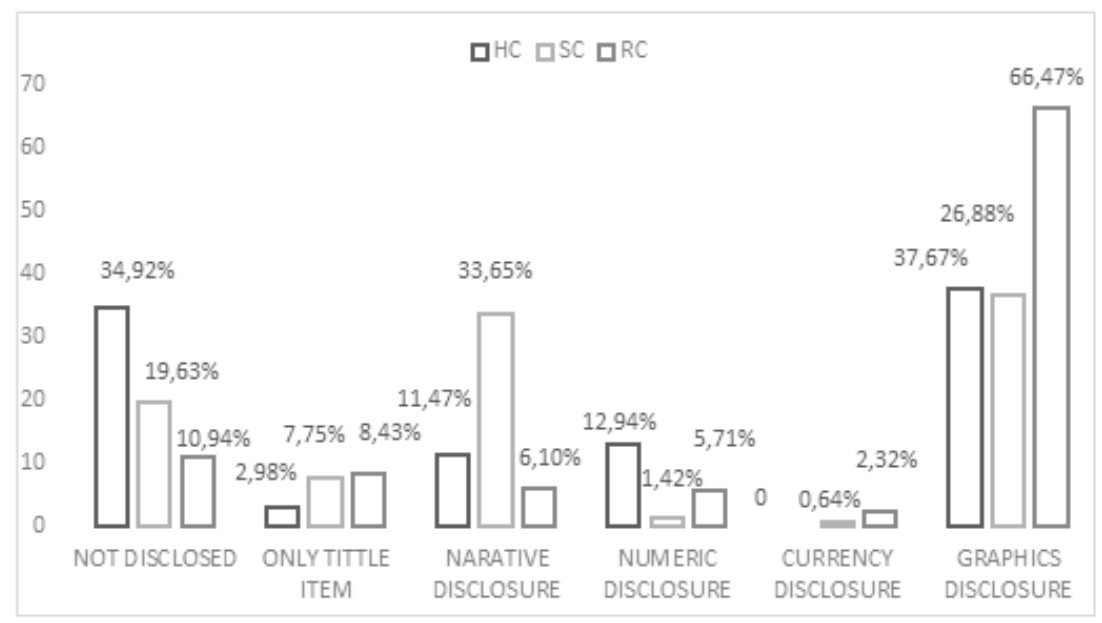

Note: HC: Human Capital; SC: Structural Capital; RC: Relational Capital

Figure 2 Percentage Disclosure of Intellectual Capital

Based on Figure 2 it can be seen that the disclosure of the highest intellectual capital component in Relational Capital of 12 items totals $89 \%$. This is due to the large number of non-vocational tertiary institutions that have revealed e-learning, library information systems that are expressed in a separate web form, and curricula that have been widely presented in the form of tables so that it is more informative. While the 
disclosure of the lowest intellectual capital component is in the human capital component. It is because the number of human capital items is the most compared to other components, in addition to the large number of universities that do not disclose information related to the workload of lecturers, the number of non-permanent lecturers, the workload of educational staff, as well as research and community service.

Furthermore, based on the figure 2 it also can be seen that the disclosure of the components of intellectual capital many were not disclosed. Overall, out of 60 the number of undisclosed items reached $65.49 \%$. The lowest item disclosure in the human capital component is the workload of lecturers, the number of non-permanent lecturers, the number of transfer students, and the workforce of educational staff. This is explained by the number of tertiary institutions which revealed that this component did not reach half of the total 86 tertiary institutions which provided information on these human capital items. The lowest item disclosure in the structural capital component is the lecturer research fund items and the dedication funds to the lecturer community. This is explained by the fact that there are still many universities that do not disclose the nominal value of research funding or community service because this item relates to accountability reports that are rarely freely accessible to the general public. While in the relational capital component, more than $50 \%$ of universities do not present information on the amount of education cooperation funds. That is because many universities do not present financial information in a transparent manner as well as disclosure on structural capital items that are not widely disclosed regarding research and service funds.

The lowest component of intellectual capital disclosure is disclosure in the form of monetary format. This is explained from the 60 number of items disclosed which reached $0.65 \%$. The highest monetary disclosure is in the relational capital component, which is the item amount of research collaboration funds. However, out of 86 universities there were only six that revealed. The rest are still revealed only a lot of titles, but can not be accessed. The second lowest intellectual capital disclosure component is in the form of numbers. This is explained from the 60 number of items disclosed which only reached $1.42 \%$. Disclosure in the form of the highest number in the relational capital component, namely the item amount of research collaboration funds. However, out of 86 universities there were only 18 universities that disclosed.

The components of intellectual capital disclosure that are expressed low except in monetary and numerical form are in the title item format but there are no contents. This is explained from the 60 number of items disclosed that only reached $2.98 \%$. Disclosure is only in the form of the highest item title in the structural capital component, namely in the dedication fund items in the lecturer community (internal sources). However, from 86 universities there were only 26 universities that disclosed.

The highest intellectual capital disclosure components are in chart/chart/picture format. This is explained from the 60 number of items disclosed in the format reaching $66.47 \%$. The disclosure of the most intellectual component of capital are disclosed in graphic/chart/image format is the relational capital component. This is explained by the 
results of the most assessment revealed in the structural capital component, namely the items of international, national and regional cooperation presented by the university's website in the form of graphic/chart/picture format as proof of the cooperation that has been established and carried out. These items clearly function as the main attraction of the tertiary institution and increase the attractiveness of visitors and the publication media to be presented to the public, especially those who really need information about the tertiary institution.

The second highest intellectual capital disclosure component is in the form of narration. It is explained from the 60 number of items expressed in narrative form reaching $33.65 \%$. The most disclosed component of intellectual capital in the form of narrative is the structural capital component, namely the vision and mission items. Vision, mission, goals are a picture of the future chosen by an organization and which will be realized sometime in the allotted time. This shows that the efforts made by the university to provide a clear picture of the direction of each university in the future and of course the better the vision, mission, and goals set by each university will have an impact on the desired performance sustainability to make the best tertiary institution and increase the appeal of the people who will choose the sustainability of their education.

Of the three components of intellectual capital that must be disclosed, it still does not show equitable distribution, many items have not been disclosed by universities which are included in the ranking of the best universities in the Ministry of Research, Technology and Higher Education version. According to Ulum (2016) this is caused by the absence of university obligations in disclosing transparency and accountability regarding the importance of disclosing public information, besides that universities are not required to produce relevant annual reports but universities must implement their financial accounting systems. In line with the existence of the Republic of Indonesia (2008) regarding Public Information Openness (KIP), it can be taken into consideration in relation to the regulation of State Universities (PTN) required to report annual reports regularly, for the benefit of users in the long term.

\section{Hypothesis Testing Results}

The researcher will first present a model match table that shows whether the data tested meets the criteria (Table 5). It can be seen that APC, ARS, and AARS, each of which has $p$-values $<0.001,<0.001$, and $<0.001$, have fulfilled the criteria if $P$ value $<0$, 05 . AVIF with a value of 1,057 has met the criteria of $<=5$. AFVIF and RSCR with values of $1,266,1,000$, respectively, when viewed from the criteria, have shown an ideal number with criteria $<=5$ and the ideal size is $<=3.3$ for AFVIF, while RSCR criteria are $>=$ 0.9 with the same ideal number, namely $=1$. GoF with a value of 0.592 indicates a large number with criteria $>=0.36$, while for small and medium criteria have criteria $>=$ 0.1 , and $>=0.25$. SSR with a value of 1,000 has met the criteria, which criteria are $>=$ 0.7 . It can be concluded that the data tested fulfilled all the criteria. 
Tabel 5 Model fit and quality indices Independent Variable to Dependent Variable

\begin{tabular}{lll}
\hline Model fit and quality indices & Index & P-Value \\
\hline Average path coefficient (APC) & 0.300 & $\mathrm{P}<0.001$ \\
Average R-squared (ARS) & 0.350 & $\mathrm{P}<0.001$ \\
Average adjusted R-squared (AARS) & 0.326 & $\mathrm{P}<0.001$ \\
Average block VIF (AVIF) & 1.057 & \\
Average full collinearity VIF (AFVIF) & 1.266 & \\
Tenenhaus GoF (GoF) & 0.592 & \\
R-squared contribution ratio (RSCR) & 1.000 & \\
Statistical suppression ratio (SSR) & 1.000 & \\
\hline
\end{tabular}

\section{Evaluation of Structural Model (Inner Model)}

The evaluation of PLS models is done by measurement models, commonly called outer models and structural models, or are called inner models. The inner model is a structural model used to predict causality relationships between latent variables between constructs (Sholihin \& Ratmono, 2013). In this study researchers only used one model, namely the inner model because the data obtained were not generated from the questionnaire.

Table 6 Adjusted $R^{2}$ and $Q^{2}$ values

\begin{tabular}{ccc}
\hline Variable & Adjusted $\mathbf{R}^{2}$ & $\mathrm{Q}^{2}$ \\
\hline Intellectual Capital Disclosure & 0.326 & 0.354 \\
\hline
\end{tabular}

Testing the inner model can be in the form of Adjusted $R^{2}$ and $Q^{2}$ Adjusted. $R$ Square is used to measure the variation in the independent variable changes to the dependent variable. The higher the value of Adjusted $\mathrm{R}^{2}$, the better the prediction model of research models studied. Furthermore, a $Q^{2}$ value higher than zero shows good prediction (Sholihin \& Ratmono, 2013). The table showing the results Adjusted $R^{2}$ and $\mathrm{Q}^{2}$ as which are presented in Table 6.

$\mathrm{N}$ use values adjusted $\mathrm{R}$-square of 0.326 indicates that the age, size and accreditation may explain the intellectual capital disclosure amounted to $32.6 \%$ of the remaining $67.4 \%$ is influenced by variables other outside research model. Furthermore, the value of $Q^{2}$ obtained by 0.354 . This means that the estimation of the model shows good predictive validity because the $Q^{2}$ value is more than zero (Sholihin \& Ratmono, 2013). Table 7 shows the hypotheses testing results whilst Figure 3 depicts analysis output of WarpPLS 6.0.

Table 7 Hypothesis Test Results

\begin{tabular}{llllll} 
Hypothesis & Information & $\begin{array}{c}\text { Path } \\
\text { Coefficient } \\
\text { Value }\end{array}$ & $\begin{array}{c}\text { Signification } \\
\text { Value (One- } \\
\text { Tailed) }\end{array}$ & $\begin{array}{c}\text { Interpretation of } \\
\text { direction and } \\
\text { significance }\end{array}$ & Decision \\
\hline $\mathbf{H}_{\mathbf{1}}$ & Age $\rightarrow$ ICD & 0.20 & $<0.01$ & Positive, significant & Supported \\
$\mathbf{H}_{\mathbf{2}}$ & Size $\rightarrow$ ICD & 0.34 & $<0.01$ & Positive, significant & Supported \\
$\mathbf{H}_{3}$ & Acrd $\rightarrow I C D$ & 0.36 & $<0.01$ & Positive, significant & Supported \\
\hline
\end{tabular}

Note: Age $=$ Age $;$ Size $=$ Size $;$ Acrd $=$ Accreditation $; I C D=$ Intellectual Capital Disclosure 


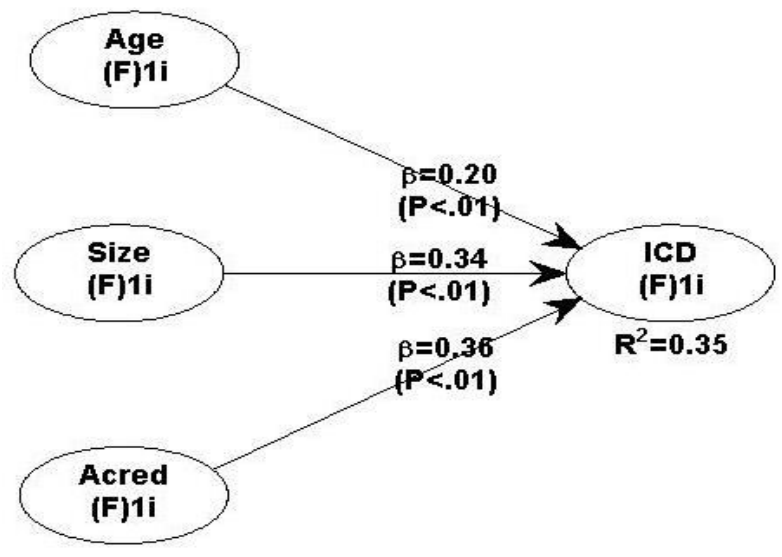

Figure 3 Output WarpPLS 6.0

\section{Discussion}

Based on the results of the presentation of descriptive statistics shows that the maximum age of tertiary education is 85 years and an average age of 50 years and above. This can indicate that the age of tertiary institutions in Indonesia is still relatively large because the average age is still in the range of 50 years and above. Size in descriptive statistics shows an average value of 4,065 and a maximum value of 16,965, meaning that the average size (number of students, lecturers, faculties, study programs) at universities in Indonesia is relatively large. The accreditation status in descriptive statistics shows an average value of 3.28 while the maximum value is 4.00 . This shows that the average accreditation at tertiary institutions in Indonesia is still relatively small because it ranges between the accreditation scores of $B$.

Based on the results of intellectual capital disclosure testing in 86 (eighty-six) best nonvocational tertiary institutions in Indonesia when viewed in terms of disclosure of the components of human capital, structural capital and relational capital , the highest disclosure is in the structural capital component, amounting to $80.36 \%$ and the lowest disclosure was in the human capital component with a percentage of $65.07 \%$. The thing that causes the disclosure of the low human capital component is because many universities do not disclose information related to the lecturer workload, the number of non-permanent lecturers, the lecturer workload, the workforce of educational staff and research paying between lecturers and students. The most disclosure of all components of intellectual capital is at Yogyakarta State University with a total disclosure of 57 items from a total of 60 items of intellectual capital components. While the lowest intellectual capital item disclosure with the number of disclosures is only 31 items at the Malang Institute of Technology.

In line with stakeholder theory which says that an organization is required to carry out activities expected by the stakeholders and has the right to disclose these activities to stakeholders. Therefore, disclosure of intellectual capital is one of the important things that needs to be reported to stakeholders because the information related to the 
company is not only limited to financial reports but information on intellectual capital is also crucial (5) .

In a study conducted by Pratiwi (2012), said that making annual reports by universities in Indonesia is still very rare, even though in some countries (for example in Europe, Australia and Singapore), universities have delivered annual reports regularly every year, which can be accessed through the university's official website. The information presented in the annual report can be more accurate and traceable than the information posted on the university's website. Annual reports are usually presented in pdf format so that they are more "established" as information that does not change as information on the website can change at any time. But in fact to get information in the annual report is very difficult because universities rarely update the information in the media.

\section{Effect of Age on Intellectual Capital Disclosure}

Based on the test results show that the first hypothesis is accepted that age has a significant effect on intellectual capital disclosure. Judging from the descriptive data on descriptive statistics shows the average age of tertiary institutions in Indonesia is relatively large because the average age is still above 50 years with a maximum value of 85 years. In stakeholder theory states that an organization cannot act in its own interests but must also provide benefits to stakeholders and report the results of their activities through reporting and disclosure.

The test results in this study support the research conducted by Banks et al. (1997) which states that universities which are more established or earlier established tend to have better disclosure quality than new universities in terms of service of financial performance. This is also reinforced by research conducted by Ismail and Bakar (2011) which examines the level of accountability for information disclosure in annual reports and websites at Malaysian state universities. The test results in his research stated that the more established universities revealed more information on their annual reports and websites compared to the newly established universities. With an older age, there is also more information owned so that the information disclosed is higher.

From the test results and seen in the results of previous studies which strengthen the results of this study can show that the older the age of a university, the more information will be disclosed and the higher the disclosure of intellectual capital, and vice versa the younger the age of a university then the information available is still and the disclosure of intellectual capital at the university will be even lower.

\section{Effect of Size on Intellectual Capital Disclosures}

Based on the test results show that the second hypothesis is accepted that the size of the university measured by the number of students, lecturers, faculty and study programs has a positive effect on intellectual capital disclosure. In the presentation of descriptive data on descriptive statistics shows an average value of 4065 and a 
maximum value of 16,965 , meaning that the average size (number of students, lecturers, faculties, study programs) at universities in Indonesia is relatively large. These results are in line with legitimacy theory, which states that the company's size will also increase the responsibility held by the company to the community. One type of responsibility is to report the company's intellectual capital. This also relates to stakeholder theory stating an organization cannot act in its own interests but must also provide benefits to its stakeholders and report the results of their activities through reporting and disclosure. Therefore, from the perspective of stakeholder theory, a website can be a balanced and efficient means of communication to meet accountability to university stakeholders (Ismail \& Bakar, 2011) .

This study supports research conducted by Fathony and Ulum (2018) which states that company size has a significant effect on intellectual capital disclosure. In Fathony and Ulum's research (2018), using the 44 best state universities in Indonesia version 4 of the International Colleges and Universities (4ICU) in 2018 as the object of study. In the study the second variable is the size calculated from the number of students and produces a significant probability under $0.05(5 \%)$, and $t$ arithmetic 3,806 which means greater than $t$ table is 2,021. This shows that the size (number of students) of state tertiary institutions significantly influences intellectual capital disclosure. Penelitian also strengthens research conducted by Aprisa, Tanjung, and Silfi (2016) who studied the disclosure of intellectual capital in the company. In his research stated that the influence of company size variables on the disclosure of intellectual capital, it is because the greater the size of a company, the higher the demands for information disclosure compared to smaller companies.

The influence between the measures on the disclosure of intellectual capital in tertiary institutions indicates that the larger the size of a tertiary institution, the greater the disclosure of intellectual capital by the tertiary institution, because the disclosure is highly needed by the stakeholders of the tertiary institution.

\section{Effect of Accreditation Status on Intellectual Capital Disclosure}

Based on the test results show that the third hypothesis is accepted that accreditation has a significant effect on intellectual capital disclosure. The test results show that there is a relationship between the variables of accreditation status of a tertiary institution to the openness or disclosure of intellectual capital information at a tertiary institution. The status of accreditation in descriptive statistics shows an average value of 3.28 while the maximum value is 4.00 . This shows that the average accreditation at tertiary institutions in Indonesia is still relatively small because it ranges between the accreditation scores of $B$.

In stakeholder theory suggests that the management of an organization is required to carry out activities expected by stakeholders because stakeholders have the right to know information about the activities of companies that affect them. Activities that are meant by stakeholders are activities that can bring the company in a good direction and support the good name of the company, this can be achieved one of them by 
revealing intellectual capital in the company. In line with what was stated by Purnomosidhi (2005), reporting of organizational activities is not limited to reporting economic or financial performance. Thus, reporting on intellectual capital and other information beyond mandatory disclosure is also important to do. Accreditation for a university is important for many people and is often a consideration for many people because a good accreditation status illustrates good quality in the university, so that it can achieve good accreditation for a college in its assessment can be assessed one of them from the availability information needed by assessors so disclosure of information about intellectual capital is also important.

The results of this study do not support research conducted by Fathony and Ulum (2018) which states that the status of accreditation has no significant effect on intellectual capital disclosure. Where in the study used 44 of the best state universities in Indonesia version 4 of the International Colleges and Universities (4ICU) in 2018 as the object of study and showed that the third variable, namely accreditation status, resulted in a significant probability above $0.05(5 \%)$, and a t count of -196 . This shows that the accreditation status does not significantly influence the intellectual capital disclosure of tertiary institutions because the significant probability is above $5 \%$ and the $t$ count for accreditation status is smaller than $t$ table. However, there are other studies that support the results of the study stating that the accreditation status has a significant effect on the disclosure of intellectual capital at universities, namely research conducted by Aulia, Ulum, and Wahyuni (2019) that uses 41 of the best Muhammadiyah universities in version $4 I C U$ 2018. Based on the assessment results, there are three accreditation namely A, B and C, which are given a score of " 3 " for accreditation $A$, score "2" for accreditation B and score "1" for accreditation C. After doing content analysis, it is known the level of intellectual capital disclosure (ICD) of each college. The average level of university disclosure is above average, namely IC disclosure on Human Capital items 95\%, Structural Capital 93\% and Relationall Capital 92\%.

The low level of disclosure of tertiary institutions with accreditation status other than A and $B$, is due to several universities such as Muhammadiyah University of Palu and Muhammadiyah University of Luwuk Banggai, which do not disclose the number of permanent lecturers, which overall colleges with accreditation status A and B disclose these items. Whereas most IC item disclosures were Yogyakarta Muhammadiyah University. From these results it can be drawn that states that the accreditation status influences the disclosure of intellectual capital at universities in line with Saputro, Anggraeni, and Mukhlason (2012) which states that the better the value of accreditation, will have an impact on outsiders' views on the quality of study programs and also college institution.

From the results of this study can show that the better the accreditation status of a tertiary institution, the better the tertiary institution's disclosure of intellectual capital is because basically the accreditation status of a university is an important thing that is considered by many people because good accreditation reflects good quality also in the university and is important information that must be known and disclosed. 


\section{Conclusion}

This study found that the highest IC component disclosure in the sample universities was Structural Capital. While the disclosure of the lowest intellectual capital component is in human capital. Furthermore, from 86 universities, the highest number of IC disclosures was by Yogyakarta State University, while the university that revealed the lowest IC was the Malang National Institute of Technology which only revealed 31 items from a total of 60 items of intellectual capital component disclosure. Of the 3 (three) independent variables studied, all variables have a positive effect on IC disclosure.

A study certainly has limitations B ome limitations in this study first is $d$ ata ICD variables can only be measured in time for the media to find the data in the form of official university website is dynamic and continuously updated historical data. Second, there is limited website access, where some websites cannot be accessed or accessed but do not display the information needed by researchers. Departing from these limitations, it may be possible to conduct further research using the university's annual report as a unit of analysis and data source if available, so that data may be available more fully and panel data testing can be carried out.

\section{References}

Aprisa, R., Tanjung, A. R., \& Silfi, A. (2016). Pengaruh Ukuran Perusahaan, Profitabilitas, Tipe Auditor dan Tipe Industri terhadap Pengungkapan Modal Intelektual (Studi Empiris pada Perusahaan yang Termasuk dalam Indeks Kompas 100 Tahun 2014 Bursa Efek Indonesia). Riau University.

Aulia, D., Ulum, I., \& Wahyuni, E. D. (2019). Pengaruh Ukuran, Kompleksitas, Program Internasional, dan Status Akreditasi Terhadap Pengungkapan Intellectual Capital Pada Universitas Muhammadiyah Di Indonesia. Jurnal Akademi Akuntansi (JAA), 2(2), 5872. https://doi.org/10.22219/jaa.v2i2.10152

Banks, W., Fisher, J., \& Nelson, M. (1997). University Accountability in England, Wales, and Northern Ireland: 1992-1994. Journal Of International Accounting Auditing \& Taxation, 6(2), 211 - 226. https://doi.org/10.1016/s1061-9518(97)90006-9

Bukh, P. N., Nielsen, C., Gormsen, P., \& Mouritsen, J. (2005). Disclosure of information on intellectual capital in Danish IPO prospectuses. Accounting, Auditing \& Accountability Journal, 18(6), 713-732. https://doi.org/10.1108/09513570510627685

Cañibano, M. L., \& Sanchez, P. (2008). Intellectual capital management and reporting in universities and research institutions. Estudios de economía aplicada, 26(2), 7-25.

Clarke, M., Seng, D., \& Whiting, R. H. (2011). Intellectual capital and firm performance in Australia. Journal of Intellectual Capital. 12(4), 505-530.

https://doi.org/10.1108/14691931111181706

Cooper, D., \& Schindler, P. (2001). Business Research Method. Ner York: McGraw Hill International Edition.

Deegan, C. (2004). Financial Accounting Theory. Sydney: McGraw-Hill Book Company.

Deegan, C., \& Soltys, S. (2007). Social accounting research: An Australasian perspective. Paper presented at the Accounting Forum. Retrieved from https://www.researchgate.net/publication/247635010 Social accounting research An Australasian perspective 
Deegan, C., \& Unerman, J. (2011). Unregulated corporate reporting decisions: considerations of systemsoriented theories: Financial accounting theory. London: McGraw-Hill.

Fathony, M. M., \& Ulum, I. (2018). University'characteristics, accreditation status, and intellectual capital disclosure: evidence from Indonesia. International Journal of Economics and Research, 9(6), 23-36.

https: / www.google.com/url? sa =t\&rct=j\&q=\&esrc=s\&source=web\&cd $=\& \mathrm{cad}=$ rja \&uact $=8 \& v e d=2$ ahUKEwj5sKW92IfqAhWB4XMBHfKeA6YQFjAAegQIAhAB\&ur l=https $\% 3 \mathrm{~A} \% 2 \mathrm{~F} \% 2 \mathrm{Fwww} . \mathrm{ijeronline.com} \% 2 \mathrm{Fdocuments} \% 2 \mathrm{Fvolumes} \% 2 \mathrm{~F} 2018 \% 2 \mathrm{~F}$ Nov $\% 2520$

$\% 2520 \mathrm{Dec} \% 252018 \% 2 \mathrm{Fijer} \% 2520 \mathrm{v} 9 \mathrm{i} \% \% 2520$ nd(3).pdf\&usg=AOvVaw1OTZrgPAA $1 \mathrm{zJNgdoavz78 \textrm {r }}$

Fazlagic, A. (2005). Measuring the intellectual capital of a university. Trabajo presentado en Trends in the management of human resources in higher education. París, Francia. Retrieved from

https:/ / www.google.com/url?sa=t\&rct=j\&q=\&esrc=s\&source=web\&cd=\&cad=rja \&uact $=8 \& v e d=2$ ahUKEwjK5ojT2IfqAhX563MBHSZMBYgQFjAAegQIARAB\&url =https $\% 3 \mathrm{~A} \% 2 \mathrm{~F} \% 2 \mathrm{Fwww}$.oecd.org $\% 2$ Feducation $\% 2$ Fimhe $\% 2 \mathrm{~F} 35322785$.pdf\&usg= AOvVaw1cRQMXXk7nsn4ZGcQEMBuO

Freeman, R. E., \& Reed, D. L. (1983). Stockholders and stakeholders: A new perspective on corporate governance. California Management Review, 25(3), 88-106.

https://doi.org/10.2307/41165018

Guthrie, J., Petty, R., Yongvanich, K., \& Ricceri, F. (2004). Using content analysis as a research method to inquire into intellectual capital reporting. Journal of Intellectual Capital, 5(2), 282-293. https://doi.org/10.1108/14691930410533704

Ismail, S., \& Bakar, N. B. A. (2011). Reporting Practices Of Malaysian Public Universities: The Extent Of Accountability Disclosure. African Journal of Business Management, 5(15), 6366-6376. https://doi.org/10.5897/AJBM10.1350

Kamal, B., \& Rahmadiane, G. D. (2017). Pengaruh Persepsi, Akreditasi Prodi, Dan Promosi Terhadap Keputusan Memilih Program Studi Akuntansi Pada Politeknik Harapan Bersama. Jurnal Inspirasi Bisnis Dan Manajemen, 1(2), 145-158. https://doi.org/10.33603/jibm.v1i2.866

Kong, E., \& Bezhani, I. (2010). Intellectual capital reporting at UK universities. Journal of Intellectual Capital, 11(2), 179-207. https://doi.org/10.1108/14691931011039679

Leitner, K.-H. (2004). Intellectual capital reporting for universities: conceptual background and application for Austrian universities. Research evaluation, 13(2), 129-140. https://doi.org/10.3152/147154404781776464

Orens, R., Aerts, W., \& Lybaert, N. (2009). Intellectual capital disclosure, cost of finance and firm value. Management Decision, 47(10), 1536-1554. Retrieved from https://pdfs.semanticscholar.org/cb44/342f848148de5424d2b5e07c5eb0a3296b8c.pd $\underline{\mathrm{f}}$

Pratiwi, R. Y. (2012). Analisis Praktik Pengungkapan Intellectual Capital Pada Website Universitas Peraih QS-Star 2011. Jurnal Reviu Akuntansi dan Kenangan, 2(2), 323-334. https://doi.org/10.22219/jrak.v2i2.1078

Purnomosidhi, B. (2005). Analisis empiris terhadap determinan praktik pengungkapan modal intelektual pada perusahaan publik di BEJ. TEMA (Telaah Ekonomi, Manajemen, dan Akuntansi), 6(2), 87-99. Retrieved from https:/ $/$ www.google.com/url? sa =t\&rct=j\&q=\&esrc=s\&source=web\&cd $=\& c a d=$ rja \&uact $=8 \& v e d=2$ ahUKEwj3uM3w7o qAhUHYysKHfKLDrkQFjABegQIBRAB\&url $=$ http $\% 3 \mathrm{~A} \% 2 \mathrm{~F} \% 2$ Fpurnomo.lecture.ub.ac.id $\% 2 \mathrm{Ffiles} \% 2 \mathrm{~F} 2012 \% 2 \mathrm{~F} 02 \% 2 \mathrm{FD}$ itermina n-Modal-Intelektual.pdf\&usg=AOvVaw0kW9Bx83YSwgqxO0hVqS8c 
Saputro, F. C., Anggraeni, W., \& Mukhlason, A. (2012). Pembuatan Dashboard Berbasis Web Sebagai Sarana Evaluasi Diri Berkala untuk Persiapan Penilaian Akreditasi Berdasarkan Standar Badan Akreditasi Nasional Perguruan Tinggi. Jurnal Teknik ITS, 1(1), A397-A402. http://dx.doi.org/10.12962/j23373539.v1i1.1141

Sholihin, M., \& Ratmono, D. (2013). Analisis SEM-PLS dengan WarpPLS 3.0 untuk Hubungan Nonlinier dalam Penelitian Sosial dan Bisnis. Yogyakarta: Penerbit ANDI.

Tran, N. P., \& Vo, D. H. (2020). Human capital efficiency and firm performance across sectors in an emerging market. Cogent Business \& Management, 7(1), 1738832. https://doi.org/10.1080/23311975.2020.1738832

Ulum, I., \& Novianty, N. (2012). Analisis Faktor-Faktor Yang Mempengaruhi Pengungkapan Intellectual Capital Pada Official Website Perguruan Tinggi Indonesia. Prosidings Simposium Nasional Akuntansi, 15, 1-22. Retrieved from http://pdeb.fe.ui.ac.id/?p=6275

Ulum, I., Harviana, R. R., Zubaidah, S., \& Jati, A. W. (2019). Intellectual capital disclosure and prospective student interest: an Indonesian perspectives. Cogent Business \& Management(just-accepted), 1707041. https://doi.org/10.1080/23311975.2019.1707041

Ulum, I., Malik, M., \& Sofyani, H. (2019). Analisis pengungkapan modal intelektual: Perbandingan antara universitas di Indonesia dan Malaysia. Jurnal Ekonomi dan Bisnis, 22(1), 163-182. https://doi.org/10.24914/jeb.v22i1.2343 